\title{
Occurrence of Hymenoptera on Sus scrofa carcasses during summer and winter seasons in southeastern Brazil
}

\author{
Leonardo Gomes ${ }^{1}$, Guilherme Gomes ${ }^{1}$, Helena Gutierrez Oliveira ${ }^{1}$, José Jordan Morlin Junior ${ }^{1}$, \\ Ivan Cesar Desuo ${ }^{1}$, Margareth M. Carvalho Queiroz ${ }^{2}$, Edilberto Giannotti ${ }^{1} \&$ Cláudio José Von Zuben $^{1}$
}

\begin{abstract}
${ }^{1}$ Av. 24A, 1515, Depto de Zoologia, UNESP, Bairro Bela Vista, 13506-900 Rio Claro-SP. leugomes@ yahoo.com.br
${ }^{2}$ Fundação Oswaldo Cruz, Instituto Oswaldo Cruz, Departamento de Biologia. Av: Brasil, 4365 Manguinhos 21040-900, Rio de Janeiro-RJ, Brasil Caixa Postal 926.
\end{abstract}

\begin{abstract}
Occurrence of Hymenoptera on Sus scrofa carcasses during summer and winter seasons in southeastern Brazil. Considerable importance has been given to nest construction and larval food transport to the nest as a precondition for the eusociality of insects. Most adult hymenopterans feed on liquids, although bees and a few wasps may also feed on pollen. Carrion represents an additional source of protein for some species and they will scavenge for dead animals in the wild. This paper aims at analyzing Hymenoptera visitors on a pig carcass during the process of decomposition, in the summer of 2005 and the winter of 2006 in Brazil, and comparing the results with other studies in the Neotropical region. To our knowledge, this is the first study which described the occurence of Agelaia pallipes, Polybia paulista and Scaptotrigona depilis on decomposing carcasses in southeastern Brazil. It also raises the hypothesis of possible applications of Hymenoptera to achieve more precise PMI estimations, apart from other insects already known as having great importance in such estimates.
\end{abstract}

KEYWORDS. Forensic Entomology; post mortem interval.

RESUMO. Ocorrência de Hymenoptera em carcaças de Sus scrofa durante as estações de inverno e verão do sudeste do Brasil. Considerável importância tem sido dada às construções de ninhos e transporte de alimento larval para o ninho como uma pré-condição para a eusociabilidade dos insetos. Muitos adultos de himenópteros alimentam-se em líquidos, embora as abelhas e poucas vespas podem também se alimentarem de pólen. Carcaças representam uma fonte adicional de proteína para algumas espécies e elas foram uma vez observadas se alimentando de animais mortos na natureza. Este trabalho tem por objetivo analisar Hymenoptera visitantes em carcaças de porcos durante o verão de 2005 e inverno de 2006 no Brasil, ao longo dos estágios de decomposição, comparando com resultados de outros estudos na região Neotropical. Pelo nosso conhecimento, esse é o primeiro estudo que descreveu a ocorrência de Agelaia pallipes, Polybia paulista e Scaptotrigona depilis em carcaças em decomposição no sudeste do Brasil. Isso também aumenta a hipótese na possibilidade de aplicação de Hymenoptera em auxiliar a estimar o IPM de maneira mais precisa, sem levar em conta insetos que já possuem grande importância forense.

PALAVRAS-CHAVE. Entomologia forense; Intervalo Pós-Morte.

Considerable importance has been recognized to nest construction and larval food transport to the nest as a precondition for the eusociality of insects (Evans, 1958; Hunt, 1991). Most adult hymenopterans feed on liquids, although bees and a few wasps may also feed on pollen. Adult Aculeata are not herbivores, detritivores, or even carnivores in the strict sense. It is safe to affirm that nectar or nectar-like liquids, and body fluids from preys or carrion are the typical, in fact nearly exclusive, sources of adult nourishment (Hunt, 1991). Characteristics of the internal anatomy reflecting this diet are the distensible crop (that serve as a liquid reservoir) and restrictive proventriculus (that serve as a valve to facilitate rapid feeding while regulating flow into the midgut). Such adaptations can be used to regurgitate liquids and are secondary adaptations that contribute significantly to the characteristic nutritional interdependence among individuals in most hymenopteran societies (Hunt, 1991).
The main food resource for all wasps larvae is insect flesh (mostly caterpillars) and spiders. Carrion represents an additional source of protein for some species. Some wasps (e.g. Vespula vulgaris Linnaeus, Vespula germanica Fabricius and Vespula pensylvanica Saussure) are often pests in food shops and manufacturing premises, where they cut small pieces from meat and fish. They will scavenge for dead animals in the wild, and they were once observed cutting pieces from the ears of live pigs in a farm (Edwards, 1980).

Some studies on control of wasps in urban areas have already been done using baits containing slow-acting insecticides. Animal protein baits (horsemeat, tinned cat or dog food, and fish) have the important disadvantage that they quickly dry up, putrefy or mould, rendering them unattractive to wasps. In the U.K. these foods remain palatable for only one or two days, which means that they have to be frequently replaced (Edwards, 1980). Carrion may be an important food 
source for social wasps (Vespidae) and bees (Apidae) in the Neotropical region. O'Donnell (1995) presented a review along with new data on epiponine wasps in Central and South America.

In that study (O'Donnell 1995), nineteen species of six genera have been reported as carrion collectors, most of them belonging to the genera Agelaia Lepeletier and Angiopolybia Araujo. One additional species and genus (recorded as Parachartergus apicalis (Fabricius), but most probably Parachartergus pseudapicalis Willink; Garcete-Barrett 1999) has been included based on indirect evidence from a 'smelling as rotting meat' colony (Bertoni 1912).

Regarding social bees, a number of stingless bee species have been observed collecting meat or juices from carcasses, and species of the Trigona hypogea Silvestri group are obligate necrophages (Schwarz 1948; Roubik 1982; Camargo \& Roubik 1991). In T. hypogea and related species, pieces of flesh are not directly transported as such to the nest, being chewed and ingested at the feeding site, and contents from the crop are subsequently regurgitated to other workers in the nest. Current evidence indicates that flesh is either metabolized into proteinaceous glandular secretions (Camargo \& Roubik 1991) or stored in protein storage pots mixed with honey (Noll et al . 1997; Serrão et al . 1997) to be used for nutrition of the larvae.

In epiponine wasps, carrion is apparently given to the larvae in the nest in the same way as insect preys. Foragers typically cut out meat pieces, using mandibles and forelegs to turn them into a ball, and then fly back with their load (O'Donnell 1995). Gambino (1993) reported antibiotic properties of the saliva of necrophagous wasps' larvae of the subfamily Vespinae, which may ensure the safe use of carrion for larval food.

Thus, this paper aims at analyzing Hymenoptera visitors on a pig carcass during the process of decomposition, in the summer of 2005 and the winter of 2006 in Brazil, and comparing the results with other studies in the Neotropical region (O'Donnell 1995, Silveira et al. 2005).

Pig carcasses weighting $11.20 \mathrm{~kg}$ (summer 2005) and 13.34 $\mathrm{kg}$ (winter 2006) were placed in an open field area inside the university campus of Instituto de Biociências, UNESP, Rio Claro, SP, Brazil (22 $22^{\circ} 5^{\prime \prime} \mathrm{S} ; 47^{\circ} 32^{\prime} 32.28^{\prime \prime} \mathrm{W}$ ) from January to March of 2006 and from June to August 2006, respectively. They were placed in the center of a $30 \times 30 \mathrm{~m}$ area composed of "terra roxa" soil, inside a large cage to avoid interference from vertebrates.

Each day at 6:00-8:00 am, 12:00-14:00 and 18:00-20:00, the decomposition state of the pig carcass was photographed and tape recorded. Specimens of Hymenoptera were collected with an entomological net.

The stages of decomposition as defined by Payne (1965) are: fresh stage, bloated stage, active decaying stage, advanced decaying stage and remain stage. Identification of wasp adults was carried out using keys from: Triplehorn and Johnson 2005 and Richards 1978.

We collected the wasps Agelaia Pallipes (89 specimens),
Polybia paulista (39), Agelaia vicina (27) and Polybia ignobilis (1), the bees Scaptotrigona delipis (74) and Apis mellifera (44) and the ant Pachycondyla obscuricornis (52).

According to the decomposition stages, the following Hymenoptera distribution was recorded:

Fresh stage. During this period, we collected specimens of: Agelaia pallipes (56 at summer and 31 at winter), Agelaia vicina (27 at summer), Apis mellifera (30 at summer and 6 at winter), Polybia paulista (13 at summer and 6 at winter), Pachycondyla obscuricornis (10 at summer) and Scaptotrigona depilis (12 at summer and 10 at winter).

Bloated stage. On this period, we collected specimens of: Agelaia pallipes (1 at summer and 1 at winter), Apis mellifera (1 at summer and 4 at winter), Polybia paulista ( 9 at summer and 4 at winter), Pachycondyla obscuricornis (13 at summer) and Scaptotrigona depilis (10 at summer and 8 at winter).

Active decaying stage. During this stage, we collected specimens of: Apis mellifera (3 at winter), Cynipidae (1 at winter), Polybia ignobilis (1 at winter), Polybia paulista (2 at summer and 2 at winter), Pachycondyla obscuricornis (20 at summer), Scaptotrigona depilis (13 at summer and 5 at winter)

Advanced decaying stage. On this period, we collected specimens of: Polybia paulista (1 at summer and 2 at winter), Pachycondyla obscuricornis (8 at summer), Scaptotrigona depilis (6 at summer and 10 at winter).

Remains stage. During this stage, we collected only Pachycondyla obscuricornis (1 at summer).

Silveira et al. (2005) performed a similar study with social wasps and bees caught with carrion traps in a 'terra firme' rainforest in Caxiuanã, PA, Brazil. Six species of epiponine wasps were captured. Angiopolybia pallens was the most frequent species, being caught in approximately $43.5 \%$ of the trials, followed by Angiopolybia paraensis (15.8\%), Agelaia fulvofasciata (5.6\%) and Agelaia angulata (3.3\%). A single individual from both Agelaia pallipes and Agelaia cajennensis were captured. Twelve species of social bees were captured. The genera Trigona, Partamona and Melipona presented similar numbers of collected species, but frequencies varied considerably. Only one specimen of Apis mellifera was captured.

To our knowledge, this is the first study which describes the occurence of Agelaia pallipes, Polybia paulista and Scaptotrigona depilis on decomposing carcasses of southeastern Brazil. Probably, all wasp and bee species recorded visiting the $S$. scrofa corpse during both seasons did so exclusively to feed on body fluids, although wasps may have collected carrion bits to feed their larvae. In addition, Pachycondyla obscuricornis (Formicidae) specimens were observed preying on blowfly larvae and adults on the pig carcass. This fact, as emphasized by Patel (1994), shows that ecological position of the ants may vary from predators (when feeding on some insects eggs, larvae or pupae) to necrophagous (when feeding on body fluids, or on decomposing tissues) in animal carcasses. 


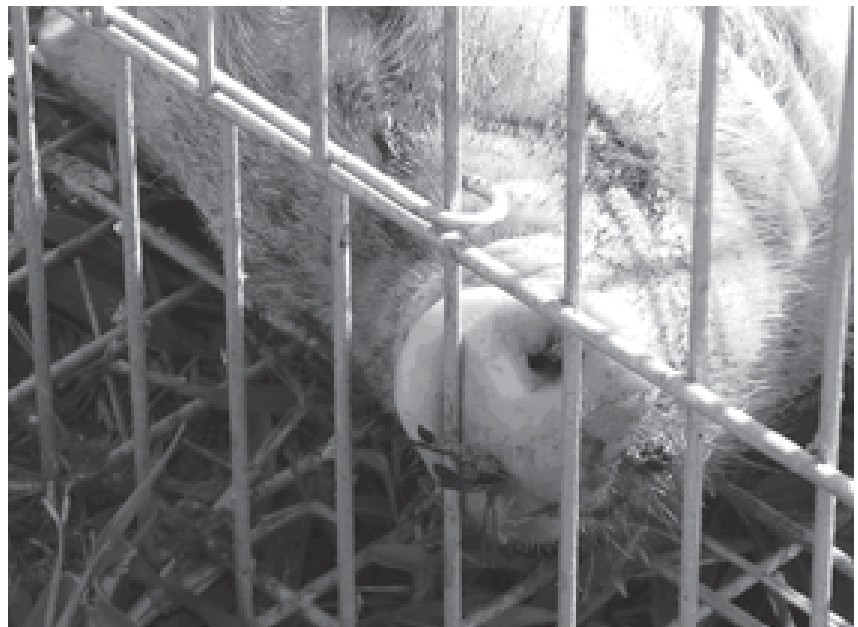

Fig 1. Agelaia pallipes specimens on the nose of the Sus scrofa carcass.

When acting as necrophages, ants may affect the decomposition process and insect colonization, and also produce artifacts that may be misinterpreted as wounds or mutilations on the cadaver, leading to errors in forensic investigations (Wells and Greenberg, 1994; Moretti and Ribeiro 2006).

There was no occurence of Agelaia vicina and Pachycondyla obscuricornis during the winter, although these were frequent on the carcass during the summer. Probably, this was due to the lack of nests around the area or perhaps due to a lower foraging activity (especially of Agelaia vicina) during the winter.

Thus, this study indicates that Agelaia pallipes is an occurring during a cadaver decayment fresh stage, suggesting that this species may be useful forensic entomologists in criminal investigations. In addition, A. pallipes usually chews surrounding tissues of natural cavities (nostrils, mouth and anus) in search for liquids. Such behavior accelerates the arrival of insects of forensic importance, especially blowflies, by widening these cavities diameter and increasing the odours exhaled from the decomposing corpse (Fig 1). This fact, associated with the knowledge on the local insect fauna forensic importance, may be of great relevancy in PMI estimation. Once both cited aspects are not considered, the PMI may be under or overestimated by finding insects on the corpse before the proper time for their occurrence.

It also raises an hypothesis on possible applications of Hymenoptera as to aid more precise PMI estimations, apart from other insects already known as having great importance in such estimatives (Gomes and Von Zuben, 2005; Gomes et al. 2006).

Acknowledgments. Authors are supported by FAPESP, Grant (03/ 00540-3 and 06/50356-2), to CNPq, to American Journal Experts (www.journalexperts.com) by reviewing the manuscript and to anonymous reviewers that corrected and improved the manuscript with their suggestions.

\section{REFERENCES}

Bertoni, W. 1912. Contribución a la biologia de las avispas y abejas del Paraguay (Hymenoptera). Anales del Museo Nacional de Historia Natural de Buenos Aires 15: 97-146.

Camargo, J. M. F. \& D. W. Roubik. 1991. Systematics and bionomics of the apoid obligate necrophages: the Trigona hypogea group (Hymenoptera: Apidae; Meliponinae), Biological Journal of the Linnean Society 44: 13-39.

Edwards, R. 1980. Social Wasps. Their biology and control. Rentokil, Felcourt. 398 p.

Evans, H. E. 1958. The evolution of social life in wasps. Proc. 10 $^{\text {th }}$. Int. Congr. Ent., Montreal 2: 449-457.

Gambino, P. 1993. Antibiotic activity of larval saliva of Vespula wasps. Journal of Invertebrate Pathology 61: 110.

Garcete-Barrett, B. R. 1999. Guía ilustrada de las avispas sociales del Paraguay (Hymenoptera: Vespidae: Polistinae). The Natural History Museum, London.

Gomes, L. \& C. J. Von Zuben. 2006. Forensic entomology and the main challenges in Brazil. Neotropical Entomology 35: 1-11.

Gomes, L.; Godoy, W. A. C. \& C. J. Von Zuben. 2006. A review of postfeeding larval dispersal in blowflies: implications for forensic entomology. Naturwissenschaften 93: 207-215.

Hunt, J. H. 1991. Nourishment and the evolution of the social Vespidae. p. 426-450. In: Ross, G. K. \& R. W. Matthews. (eds.) The social biology of wasps. Comstock, Ithaca. $678 \mathrm{p}$.

Moretti, T. C. \& O. B. Ribeiro. 2006. Cephalotes clypeatus Fabricius (Hymenoptera: Formicidae): Hábitos de Nidificação e Ocorrência em Carcaça Animal Neotropical Entomology 35: 412-415.

Noll, F.; R. Zucchi, R.; J. A. Jorge \& S. Mateus. 1997. Food collection and maturation in the necrophagous stingless bee, Trigona hypogea (Hymenoptera: Meliponinae). Journal of the Kansas Entomological Society 69: 287-293.

O'Donnell, S. 1995. Necrophagy by neotropical swarm-founding wasps (Hymenoptera: Vespidae, Epiponinai). Biotropica 27: 133-136.

Patel. F. 1994. Artifact in forensic medicine: Postmortem rodent activity. Journal of Forensic Science 39: 257-260.

Payne, J. L. 1965. A summer study of the baby pig Sus scrofa Linnaeus. Ecology 46: 592-602.

Richards, O. W. 1978. The Social Wasps of the Americas, excluding the Vespinae. British Museum (Natural History), London. 584 p.

Roubik, D. W. 1982. Obligate necrophagy in a social bee. Science 217: 1059-1060

Schwarz, H. F. 1948. Stigless bees (Meliponinae) of the Western Hemisphere. Bulletin of the American Museum of Natural History 90: $1-546$.

Serrão, J. E.; C. Cruz-Landim \& R. L. M. Silva-de-Moraes. 1997. Morphological and biochemichal analysis of the stored and larval food of an obligate necrophagous bee, Trigona hypogea. Insectes Sociaux 44: 337-344.

Silveira, O.T.; M. C. Esposito; J. N. Santos-Jr \& F. E. Gemaque-Jr. 2005. Social wasps and bees captured in carrion traps in a rainforest in Brazil. Entomological Science 8: 33-39.

Triplehorn, C. A. \& N. F. Johnson. 2005. Borror and DeLong's Introduction to the Study of Insects. $7^{\text {th }}$. Ed. Thomson, Belmont. $864 \mathrm{p}$.

Wells, J. D. \& B. Greenberg. 1994. Effect of the imported fire ant (Hymenoptera: Formicidae) and carcass type on the daily occurrence of postfeeding carrion-fly larvae (Diptera: Calliphoridae, Sarcophagidae). Journal of Medical Entomology 31: 171-174. 